\title{
THE FEATURES OF FLAME TEMPERATURE MEASUREMENT
}

\begin{abstract}
The flame temperature measurement gives the understanding of combustion processes and is important for the temperature control systems. In this paper the review and analyze of the methods of flame temperature measurement are represented. Each of them is effective under certain condition. Nowadays the method of Raman-scattering is promising in this field. It pretends to avoid some of the errors in other existing techniques.
\end{abstract}

Keywords: Raman scattering, contact and non-contact methods, the issues of the measurement, Stokes line, anti-Stokes line.

\section{Introduction}

Approximately $30 \%$ of all measurements in research and industry are the temperature measurements, because of their role in understanding physical, chemical and biological processes. Flame temperature measurement is important for solving such problems, as research and optimization of combustion processes in metallurgical furnaces, internal combustion engines, reaction engine etc.

\section{The issues of flame temperature measurement}

In the range of high temperatures the accuracy and reliability of measurement results are strongly reduced. There are several reasons for this. First, the flame doesn't remain in the complete thermodynamic equilibrium. A large amount of energy is released during the process of burning. It is unevenly distributed on degrees of freedom of molecules. Therefore we can speak

\footnotetext{
${ }^{1}$ Corresponding author: Veronika Herasymenko, Lviv Polytechnic National University, Stefana Bandery 12, Lviv Oblast, Ukraina, 79000, herasymenkoveronika@gmail.com

${ }^{2}$ Oleh Seheda, Lviv Polytechnic National University, Stefana Bandery 12, Lviv Oblast, Ukraina, 79000

${ }^{3}$ Bohdan Stadnyk, Lviv Polytechnic National University, Stefana Bandery 12, Lviv Oblast, Ukraina, 79000
} 
separately of three values of energy and temperatures, which correspond to the effective rotation, vibration and translation energies of the molecules. Second, the flame contains active substances such as free radicals $\mathrm{OH}$ and $\mathrm{CH}$, which can react with any surface placed into the flame. The heat released during the reaction can heat the surface to a temperature higher than the temperature of the flame. Also a wide temperature range, temperature gradient and dynamics of combustion processes are typical for flame. Phenomenon of chemiluminescence is undesirable during the temperature measurement.

The presence of such amount of undesirable effects on measurement explains the existence of a number of different methods and measurement tools. Each of them is effective under certain condition. Thus, successful measurement of temperature depends on correct choice of measurement method. In this case "successful measurement" means a measurement with a high reliability of the results and their accuracy. The purpose of this work is therefore to review and analyze the use of existing temperature measurement methods to measure the flame temperature.

\section{Review of basic existing methods for flame temperature measurement}

\subsection{Contact methods}

Contact devices, such as thermocouples, resistance thermometers and others, which are widely used to measure the temperature of solids, aren't effective in flame temperature measurement since most of them cannot withstand temperatures higher than $1500^{\circ} \mathrm{C}$. Some thermocouples of refractory alloys are used in measurements up to $3000^{\circ} \mathrm{C}$, but at such a high temperatures there are additional errors compared to the solids temperature measurement. These errors are caused by significant radiation losses, catalytic effect on combustion process, distortion of temperature field, device inertia and so on $[1,2]$. To minimize the negative effect of these factors a use of thermocouple with the least size of junction and low emissivity of surface is recommended [1]. With the help of contact devices, for example thermocouple, the local temperature can be measured in the volume proportion to approximately ten diameters junction. For the temperature fields research a matrix of thermocouples must be used. This leads to measurement complication and increased costs, but in case of flame temperature measurement, allows to explore the temperature fields and increases the reliability of measurements. Among other advantages of this method the facility of use and reasonable price should be mentioned [3]. 


\subsection{Non-contact methods}

The advantages of non-contact methods of flame temperature measurement include the lack of influence on the object which temperature is measured, high accuracy and the possibility of use for a wide temperature range. The disadvantages include: problems of the point of measurement determination in a volume; measured value usually represents the mean temperature for several intervals; the equipment for optical temperature measurements is comparatively cumbersome, expensive and sensitive to thermal and mechanical damage.

Non-contact methods of flame temperature measurement are divided into active and passive. The passive methods incorporate:

- the brightness pyrometry method, two-colour pyrometric techniques;

- the inversion technique of spectral lines;

- the absorption and emission techniques;

- the method of absolute intensity of a spectral line;

- the method of relative intensity of spectral lines (Ornstein method).

The biggest disadvantage of pyrometric technique use is a necessity of emissivity or it's change with the wavelength and its dependence of the flame thickness [4]. It is necessary to bring in the exemplary substances, for example, sodium, lithium or thallium etc. for the inversion technique of spectral lines. Additional sources of error come from the presence of solid particles in the flame: soot, liquid drops or solid crystals; light refraction on the boundary of flame etc. [5]. The absorption and emission techniques are used to study unstable flames and short processes [5]. The application of these methods must be preceded by spectral research of the object for detailed analysis of emitting properties of the medium.

Active methods are based on the object's irradiation by monochromatic light (laser) and analysis of the reflected signal. Those methods include:

- the interference method;

- the method of laser-induced fluorescence;

- the method of Raman-scattering [6,7];

- the acoustic method [6].

The equipment for these methods is more cumbersome and more expensive (because of the laser price) compared to the passive methods.

\subsection{Raman scattering}

Promising and popular in various fields (criminalistics, medicine, industry and others) is nowadays the Raman scattering spectroscopy. It's used to identify the chemical components or to investigate the intramolecular interactions.

The sample is illuminated with monochromatic light, usually with laser beam. Particles of light react with the molecules of the investigated sample. The 
spectrum of the reflected radiation contains Rayleigh lines (on the laser wavelength) and unique spectral lines with the frequency shift: Stokes and antiStokes lines. If part of the energy excites the vibrations of molecules, the scattered radiation is shifted to a lower frequency than the frequency of the laser light (Stokes shift). If the molecule gives back the vibration energy, the scattered radiation is shifted to the higher frequency (anti-Stokes shift). The temperature $(T)$ is determined by the ratio of the intensities of Stokes $\left(I_{s}\right)$ and anti-Stokes components $\left(I_{a s}\right)(1)[8]$ :

$$
\frac{I_{s}}{I_{a s}}=\left[\frac{v_{i}-v_{0}}{v_{i}+v_{0}}\right]^{4} \exp \frac{h c v_{0}}{k T}
$$

where: $v_{i}$ - laser frequency, $v_{o}-\operatorname{Raman} \operatorname{shift} ;\left(v_{i}=1 / \lambda_{i}, v_{0}=1 / \lambda_{0}\right)$,

$h$ - Plank constant,

$k$ - Boltzmann constant,

$\mathrm{c}-$ speed of the light.

The temperature of the object $T$ can be determined by the formula (2) [9]:

$$
T=\frac{h c v_{0}}{k \ln I \frac{I_{s}}{I_{a s}}-4 k \ln \frac{v_{i}-v_{0}}{v_{i}+v_{0}}}
$$

The main advantages of this method are the following: the facility in preparing the sample, a large volume of received information, a small spectrum distortion by the surrounding atmosphere and a weak Raman spectrum of glass, which is good for using the protective glasses.

\section{Conclusions}

The represented list of the flame temperature measurement methods isn't exhaustive. And none of them is universal. Often the reliable measurement results require additional information, for example, emissivity, internal flame characteristics. There may be a need to bring in additional control substances or equipment that could substantially distort the flame temperature field. While choosing a measurement method it is necessary to consider the radiation spectrum of the flame, the measurement conditions and the temporal characteristics of combustion process. The existence of a large amount of measurement influences constrains to use at least two different methods. In this case a degree of a coincidence of measurement results can serve as a criterion of their reliability. 


\section{Bibliography}

[1] Butler B.W., Shannon K.S.: A review of error associated with thermocouple temperature measurement in fire environments, 2nd International Wildland Fire Ecology and Fire Management Congress, 2003.

[2] Gill W., Donaldson A.B., Lucero R.E., Yilmaz N.: Problems encountered in fluctuating flame temperature measurements by thermocouple, Sensors, 8, pp.78827893, 2008.

[3] Teplinsky M.V., Yagodnikov D.A.: Digital processing and analysis of results visualization of fire tests of the model rocket solid-fuel engine, Vestnik MHTU Baumana, no.3, 2005, p.34-41.

[4] Gutschwager B., Hartmann J., Hollandt J.: Strahlungsthermometrie - Temperaturen berührungslos messen, Auszug aus atp-Sonderheft 6/2006 Systeme und Lösungen zur berührungslosen Temperaturmessung, pp.1-14.

[5] Gaydon A.G., Wolfhard H.G.: Flames, their structure, radiation and temperature: (3rd edition) London: Chapman and Hall Limited, 1970.

[6] Meier W., Stopper U.: Experimental study of industrial gas turbine flames including quantification of pressure influence on flow field, fuel/air premixing and flame shape, Combustion and Flame, vol.160, no.10, 2013, p.2103-2118.

[7] Atakan B., Hartlieb A.T., Kohse-Höinghaus K.: Temperature measurement in fuelrich non-sooting low-pressure hydrocarbon flames, Applied Physics B, vol.70, no.3, 2000, pp.435-445.

[8] Moore D.S.,McGrane S.D.: Raman temperature measurement, IOP Science, 2014

[9] Seheda O., Stadnyk B., Yatsyshyn S.: Metrology of Temperature Transducer based on Raman Effect, Sensors \& Transducers Journal, Vol. 177, Issue 6, June 2010, pp.78-84.

\section{CECHY POMIARU TEMPERATURY PLOMIENIA}

\section{Streszczenie}

Pomiar temperatury płomienia pozwala zrozumieć procesy spalania i jest ważnym dla systemów kontroli temperatury. W artykule przedstawiona jest analiza metod pomiaru temperatury płomienia. Każda z nich jest skuteczna przy spełnieniu pewnych warunków. W tej dziedzinie metoda rozpraszania ramanowskiego jest obecnie obiecująca. Wspomniana metoda pozwala uniknąć niektórych błędów charakterystycznych dla innych technik

Słowa kluczowe: rozpraszanie ramanowskiego, metody kontaktowe i niekontaktowe, problemy pomiaru, pasma stokesowskie i antystokesowskie.

DOI: $10.7862 /$ re.2015.32

Tekst złożono w redakcji: maj 2015

Przyjęto do druku: wrzesień 2015 

